\title{
Identification of Risk Factors And Seroprevalence for Septicemia Epizootica (SE) Endemic Case of Buffaloes in Aceh Barat, Aceh
}

\author{
Nurliana \\ Laboratory of Veterinary Public Health \\ Faculty of Veterinary Medicine, \\ Universitas Syiah Kuala \\ Banda Aceh, Indonesia \\ nurliana.nuna@unsyiah.ac.id \\ Razali \\ Laboratory of Veterinary Public Health \\ Faculty of Veterinary Medicine, \\ Universitas Syiah Kuala \\ Banda Aceh, Indonesia \\ razali@unsyiah.ac.id \\ Ismail \\ Laboratory of Veterinary Public Health \\ Faculty of Veterinary Medicine, \\ Universitas Syiah Kuala \\ Banda Aceh, Indonesia \\ ismail_nah@yahoo.com
}

\author{
Teuku Fadrial Karmil \\ Laboratory of Clinic \\ Faculty of Veterinary Medicine, Universitas \\ Syiah Kuala \\ Banda Aceh, Indonesia \\ t.fadrialkarmil@unsyiah.ac.id
}

\author{
Sugito \\ Laboratory of Clinic \\ Faculty of Veterinary Medicine, Universitas \\ Syiah Kuala \\ Banda Aceh, Indonesia \\ sugituofkhunsyiah@unsyiah.ac.id
}

\author{
Teuku Reza Ferasyi \\ Laboratory of Veterinary Public Health \\ Faculty of Veterinary Medicine, Universitas \\ Syiah Kuala \\ Banda Aceh, Indonesia \\ teuku_rezaferasyi@unsyiah.ac.id \\ Rastina Rastina \\ Laboratory of Veterinary Public Health \\ Faculty of Veterinary Medicine, Universitas \\ Syiah Kuala \\ Banda Aceh, Indonesia \\ rastina_rzl@unsyiah.ac.id
}

\begin{abstract}
This study aimed to determine the risk factors for endemic cases of Septicaemia Epizootica (SE) diseases and prevalence of immunity (antibody titer) to SE in Aceh Barat, Aceh. 336 samples of buffaloes blood were taken based on age level guided by the a stratified random sampling. Antibody titers were tested by ELISA. The risk factors of SE disease were detected by questioner. Risk factor data and its relationship respectively were analyzed by descriptive analysis, Odds Ratio and Chi-square test. The results of antibody titer seroprevalance of SE were $16.95 \%$. From five subdistricts only four subdistricts resulted positive SE antibody titers, namely Bubon subdistrict had highest seroprevalence rate $6.55 \%$, followed by Samatiga 4.16\%, Woyla Barat 4.16\%, and Meureubo 2.08\%. 43 out of 279 buffaloes $\geq 2$ years showed positive seroprevalence $12.79 \%$ and 14 buffaloes out of 57 buffaloes $\leq 2$ years showed positive seroprevalence $4.16 \%$. Buffaloes with age under two years old had the high risk to SE disease. Vaccination status, livestock traffic and age of buffaloes were risk factors for endemic cases of $\mathrm{SE}$ in Aceh Barat, Aceh.
\end{abstract}

Keyword-septicaemia epizootica, antibody titer, vaccination, buffalo, risk factor.

\section{INTRODUCTION}

Aceh Province is the province that has the highest buffalo population in Indonesia with a total buffalo population of 175.3 thousand $(12.7 \%)$ of the total national buffalo population of 1.38 million in 2014-15 [1]. One of the districts with great potential for developing buffalo cattle in Aceh province is Aceh Barat District, which is supported by a high buffalo population and is more dominant than other livestock and has extensive grazing fields as an abundant source of feed. Even though the buffalo population in Aceh is the largest in Indonesia, the buffalo population in Aceh Province, especially in West Aceh District has fluctuated. Allegedly this is due to the SE cases that are endemic. In 2006 there were 138 cases, in 2007-2008 it dropped to 28 and 18 cases, but in 2009 and 2010 there was an increase from 335 to 637 cases. The latest news is the death of livestock due to snoring in Gleng Village, Sungai Mas District, West Aceh Regency [2].

The ups and downs of SE cases in Aceh Barat District are allegedly due to the buffalo maintenance system that is still extensive (traditional) and the handling of unplanned diseases. Efforts to increase the population and improve the productivity of buffalo cattle have experienced many obstacles, especially in the field, including outbreaks of infectious animal diseases, such as snoring or Septicaemia Epizootica (SE). High levels of mortality and morbidity in water buffaloes and cattle are caused due to acute and fatal SE disease [3]. The mortality rate in buffalo and cattle in Asia due to SE disease reaches 100,000 per year [4], but buffalo is more sensitive and more severe which is characterized by subcutaneous edema [5]. Buffaloes aged 6-18 months are the group most sensitive to SE disease, so they must be given top priority in controlling disease in the field [6]. 
However, most cattle over the age of 18 months in endemic areas have naturally protective antibodies [7].

Because of the SE cases that often occur every year in West Aceh Regency, it is necessary to eradicate and control plan but has not succeeded in suppressing as few cases of the disease as possible. One of the most important policies that have been implemented is mass vaccination in Aceh Barat District which is carried out annually. However, these activities are also ineffective because they have not been carried out as a whole for all buffaloes. Besides, livestock raising systems are generally maintained in the forest, so that many animals do not get vaccinated. Based on the description of the problem, it is necessary to convey the results of a study of the occurrence of endemic cases of SE disease and the factors that influence the emergence of SE disease in Aceh Barat District.

\section{MATERIALS AND METHODS}

\section{A. Research design and sample}

This research was a field survey aimed at quantitative descriptive analysis. The sample used was 4 breeders who had the right buffalo with an average of 7 buffaloes at all age and sex levels in males and females in 5 sub-districts in the district of West Aceh. 336 buffaloes were determined based on the table of determination of the number of samples of specific populations developed by Isaac and Michael [8], with an error rate of 5\%. The sampling technique for participation was proportionate stratified random sampling. Antibody titers of SE were examined using the ELISA test. Identification of risk factors associated with the emergence of cases of SE was carried out by distributing questionnaires

\section{B. Identification of risk factors using questionnaires for farmers. \\ Identification of risk factors of SE were used farmers} as objects of data collection on their knowledge. Questions were asked to 48 farmers that contained questions about the knowledge of farmers against SE disease.

\section{Blood collection and determination of antibody titers}

Buffalo blood was taken for the use of antibody titers against SE using the ELISA test [9]. Data was interpreted form the results of the ELISA test were compared with control samples on a plate. Absorption values were recorded for each serum control. Highest dilution 1; 200 of positive control serums were given the ELISA 1024 unit value in column A11-A12, each dilution was given the ELISA unit value before from the previous ELISA unit value, namely 512 (Column B 11-B12), 256 (C11C12), 128 (D11-D12), 64 (E11-E12), and 32 (F11-F12). Serum control values taken are the average values of columns 11 and 12 in columns whose ELISA units are 128 and 256. Then the optical density (OD) is calculated. The truncated OD value obtained is the OD value of the sample per plate. Readers of test samples that are greater or equal to positive and negative OD samples. Positive SE antibody titers are expressed with protective titers against $\mathrm{SE}(\geq 200$ ELISA Units) [9].

\section{Data Analysis}

SE disease antibody titers in buffaloes were analyzed descriptively. The link between risk factors for farmers' knowledge and antibody titers was analyzed using Odds Ratio (OR) and continued Chi-quadrat test [10].

\section{RESULT}

\section{A. Protection of antibody titers for $S E$ disease in buffaloes in West Aceh District}

Seroprevalence of protective SE antibody titers in buffaloes in the Aceh Barat District was 16.95\% (57 buffaloes were positive from 336 buffaloes) (Table 1). Based on ELISA test results on 336 samples from 5 districts, only 4 districts were found to have positive SE antibody titers, namely in Bubon sub-district with the highest prevalence of $6.55 \%$, then obtained by Samatiga and West Woyla districts respectively $4.16 \%$, and the lowest prevalence of antibody titers in Meureubo District was $2.08 \%$, while Woyla sub-district was negative.

Table 1. Percentage Of Prevalence Of Protective Antibody Titer Of Buffalo In Five Sub District, West Aceh DISTRICT

\begin{tabular}{|c|c|c|c|c|}
\hline \multirow{2}{*}{ Sub District } & \multirow[t]{2}{*}{$\begin{array}{c}\text { Number of } \\
\text { Samples }\end{array}$} & \multicolumn{2}{|c|}{ ELISA test results } & \multirow[b]{2}{*}{ Prevalence $(\%)$} \\
\hline & & positive & negative & \\
\hline Samatiga & 72,00 & 14,00 & 57,00 & $4,16 \%$ \\
\hline Bubon & 114,00 & 22,00 & 93,00 & $6,55 \%$ \\
\hline Woyla & 57,00 & - & 57,00 & - \\
\hline WestWoyla & 50,00 & 14,00 & 36,00 & $4,16 \%$ \\
\hline Meureubo & 43,00 & 7,00 & 36,00 & $2,08 \%$ \\
\hline Total & 336,00 & 57,00 & 279,00 & $16,95 \%$ \\
\hline
\end{tabular}

B. Protective antibody titers for SE disease in buffaloes based on age groups in West Aceh Regency.

Antibody titers in buffaloes by age group found 43 out of 279 buffalo aged $\geq 2$ years showed antibody titers with seroprevalence of $12.79 \%$. Buffaloes aged $\leq 2$ years found 14 out of 57 animals showed protective antibody titers with seroprevalence of $4.16 \%$ (Table 2).

C. The relationship between risk factors for knowledge of farmers and SE disease-protective antibody titers in West Aceh District

Risk factors for farmer knowledge consist of the ability of farmers to characterize SE disease, the period of disease occurrence, status, and frequency of vaccination, reporting system, post-mortem handling, livestock traffic and age range of affected buffalo. Based on OR and Chisquare analysis, there are 3 risk factors from farmers' knowledge related to SE disease antibody titers in Aceh Barat District (Table 3). 
TABle 2. Percentage Of Protective Antibody Titer Seroprevalence Based On Age At Animal AfFairs In West

\begin{tabular}{lllllll}
\multicolumn{7}{c}{ ACEH DISTRICT } \\
\hline $\begin{array}{l}\text { Sub } \\
\text { district }\end{array}$ & $\begin{array}{l}\text { Number of } \\
\text { Samples }\end{array}$ & \multicolumn{2}{c}{ Positif Negative } & \multicolumn{2}{l}{$\begin{array}{l}\text { Prevalensi titer } \\
\text { antibodi }(\%)\end{array}$} \\
\cline { 2 - 7 } & $\begin{array}{l}\text { years } \\
\text { old }\end{array}$ & $\begin{array}{l}\text { years } \\
\text { old }\end{array}$ & $\begin{array}{l}\text { years } \\
\text { old }\end{array}$ & $\begin{array}{l}\text { years } \\
\text { old }\end{array}$ & $\begin{array}{l}\text { years } \\
\text { old }\end{array}$ & $\begin{array}{c}\text { years } \\
\text { old }\end{array}$ \\
\hline Samati & 50,0 & 21,0 & 14,00 & - & $4,16 \%$ & - \\
ga & 114,0 & 0 & 22,00 & - & $6,55 \%$ & - \\
Bubon & 36,0 & - & - & - & - & - \\
Woyla & 36,0 & 22,0 & - & 14,0 & - & $4,16 \%$ \\
West & 43,0 & 0 & 7,00 & 0 & $2,08 \%$ & - \\
Woyla & & 14,0 & & - & & \\
Meure & & 0 & & & & \\
ubo & & - & & & & \\
\hline Total & 279,0 & 57,0 & 43,00 & 14,0 & 12,79 & $4,16 \%$ \\
\end{tabular}

TABLE 3. LiABILITy RATIO OF FACTORS From KNOWLEDGE OF Animal Husb anders AfFecting The AFFection Of Se Disease ENDEMIC CASES IN WEST ACEH DISTRICT.

\begin{tabular}{|c|c|c|c|c|}
\hline \multirow{2}{*}{ Risk factors } & \multicolumn{2}{|c|}{ Infection Status } & \multirow[t]{2}{*}{ OR } & \multirow[t]{2}{*}{ Chi Square } \\
\hline & Positive & Negative & & \\
\hline $\begin{array}{l}\text { The characteristics } \\
\text { of SE disease } \\
\text { Make a sigh and } \\
\text { mucous out of the } \\
\text { nose } \\
\text { Drain blood from } \\
\text { the hole } \\
\text { rectum and skin }\end{array}$ & $\begin{array}{r}7,00 \\
51,00\end{array}$ & $\begin{array}{r}14,00 \\
193,00\end{array}$ & 2,64 & 0,44 \\
\hline $\begin{array}{l}\text { Cases of SE } \\
\text { disease which } \\
\text { ever happened } \\
\geq 1 \text { years } \\
\leq 1 \text { years }\end{array}$ & $\begin{array}{l}43,00 \\
15,00 \\
\end{array}$ & $\begin{array}{c}193,00 \\
86,00\end{array}$ & 1,33 & 0,75 \\
\hline $\begin{array}{l}\text { Vaccination status } \\
\text { Been vaccinated } \\
\text { Never vaccinated }\end{array}$ & $\begin{array}{l}29,00 \\
29,00 \\
\end{array}$ & $\begin{array}{c}43,00 \\
236,00 \\
\end{array}$ & 5,50 & $0,03^{*}$ \\
\hline $\begin{array}{l}\text { Vaccine } \\
\text { More than once } \\
\text { Just for Once }\end{array}$ & $\begin{array}{l}22,00 \\
36,00\end{array}$ & $\begin{array}{c}71,00 \\
207,00\end{array}$ & 1,74 & 0,49 \\
\hline $\begin{array}{l}\text { Reporting system } \\
\text { if available sick } \\
\text { cattle } \\
\text { Report to the } \\
\text { officer } \\
\text { Not report }\end{array}$ & $\begin{array}{l}29,00 \\
29,00 \\
\end{array}$ & $\begin{array}{l}129,00 \\
150,00\end{array}$ & 1,17 & 0,84 \\
\hline $\begin{array}{l}\text { Handling of cattle } \\
\text { after death } \\
\text { Digging / burying } \\
\text { Throwing it into } \\
\text { the river }\end{array}$ & $\begin{array}{c}7,00 \\
51,00\end{array}$ & $\begin{array}{c}43,00 \\
236,00\end{array}$ & 0,55 & 0,60 \\
\hline $\begin{array}{l}\text { Livestock traffic } \\
\text { From the West } \\
\text { Aceh Regency } \\
\text { From outside the } \\
\text { West Aceh } \\
\text { Regency }\end{array}$ & 29,00 & $\begin{array}{r}43,00 \\
236,00\end{array}$ & 5,50 & $0,03^{*}$ \\
\hline $\begin{array}{l}\text { Age of the animal } \\
\text { attacked by the } \\
\text { disease } \\
\geq 2 \text { years } \\
\leq 2 \text { years }\end{array}$ & $\begin{array}{l}36,00 \\
22,00\end{array}$ & $\begin{array}{c}71,00 \\
207,00\end{array}$ & 4,83 & $0,04^{*}$ \\
\hline
\end{tabular}

\section{DISCUSSION}

A. Protection of antibody titers for SE disease in buffaloes in West Aceh District

The results showed that all buffaloes were exposed naturally (Table 1). This is supported by the results of direct interviews with farmers that their buffaloes have never been vaccinated at all and even if they have been vaccinated for more than a year, the records related to vaccination are not very clear and difficult to trace. Natural immunity is generally obtained from subclinical infections. The proportions of animals with natural immunity differ from one group to another and differ from time to time and are directly related to the incidence rate of the disease [11].

Immunity characterized by protective antibodies occurs buffaloes which is exposed to SE disease and can survive more than one year later to act as a carrier for SE disease. Almost all adult animals in areas with high SE cases generally obtain immune substances naturally [7]. Buffaloes detected by protective antibody titers can cause latent infections for other sensitive animals, especially buffalo in the region so that the region is always associated with SE endemic cases, especially when the rainy season comes when many buffalo experience stress. Physiological stress in livestock can decrease the immune system, this condition will increase the incidence of disease [12]; [13].].

\section{B. Protective antibody titers for SE disease in buffaloes} based on age groups in West Aceh Regency.

Based on the results of the study there were differences in protective antibody titers by age group (Table 2). However, there were no differences in postvaccination antibody titers by age group, both in cattle and buffalo [14]. Most likely buffalo in West Aceh district had been vaccinated or still had maternal antibodies. Cows and buffaloes aged 6-18 months were very sensitive to SE disease with morbidity levels reaching $80 \%$, so priority should be given to disease control. [15]. The sensitive animal groups in endemic areas are only young animals whose maternal immunity has decreased [16].

C. The relationship between risk factors for farmers' knowledge and protective antibody titers for SE disease in Aceh Barat District

Based on the research results, breeders recognize the characteristics of SE disease and the time span of disease occurrence is not related to the protective antibody titer of SE disease (Table 3), but if the farmer does not recognize the characteristics of SE disease, the case of SE disease increases 2.64 greater than the time span of occurrence is 1.33 times. Endemicity of the disease in an area is known if a disease agent is present and a case will occur but it is unknown when the case reappears [17]. Cases of disease endemicity occur periodically annually in geographically and in the same climate and environment.

Vaccination status influences with the SE antibody titer in buffalo. If vaccination is carried out in a scheduled and timely manner it can increase immunity (antibody titer) in buffaloes 5.5 times greater when compared to buffaloes that are not vaccinated (Table 3). One of the efforts to prevent and control SE disease by conducting vaccinations every year in endemic areas [18]. Before 
vaccination, it is better to do early observation in the field (clinically and epidemiologically for cases that arise) and laboratory observations (serologically) on antibody titers [19]. Low coverage of vaccination will not be able to eradicate clinical cases in the field [20]; [21]. Based on research vaccination should be prioritized in animals aged 6-18 months to 3 years for efficient use of vaccines. Vaccination strategies need to be assessed for accuracy in the field and consider further vaccinations in endemic areas [22].

The frequency and repetition of vaccination are not unrelated to buffalo antibody titers in Aceh Barat district. The results of this study contradict the De Alwis study where re-vaccination needs to be given to cattle aged 4-6 months to provide special protection for calves because the defense system is underdeveloped despite maternal immunity from vaccinated mothers [23]. The OIE recommends that the first vaccination program in cattle should be 4-6 months old and routinely be carried out with a single dose of oil adjuvant vaccine (OAV) followed by one booster 3-6 months later and annual revaccination, if there is an SE outbreak in animals in the vaccine, one a dose of aluminum hydroxy vaccine (APV), followed by one dose of OAV [24].

Farmer awareness to report disease cases in this study did not affect the SE antibody titer which was only 1.17 times if the reporting system was not implemented compared to the running of a good and correct reporting system (Table 3). Cases of SE disease can be prevented if there is awareness among the breeders and is supported by good disease information and reporting [24]. The disease is not monitored due to the ignorance or unwillingness of farmers to report to the authorities or paramedics and veterinarians [25] The attack of SE disease in Bangladesh which caused economic losses due to underdeveloped reporting systems and the reluctance of farmers to report early if there are cases that arise [26].

Post-mortem handling by livestock farmers by disposing of cattle in rivers due to SE disease is not related to SE antibody titers. It is suspected that the antibody titer in buffaloes in West Aceh District due to natural exposure, the strength against disease agents is stronger and latent. If there is an infectious attack on buffaloes due to careless disposal of carcasses, the disease agent can likely be resisted by strong body immunity in animals exposed to nature. The outbreak of SE disease in Aceh due to the direction of river currents [27] and due to bad habits of breeders who throw carcasses of SE diseased cattle into the river carelessly [28].

Livestock traffic has a significant effect on protective antibody titers (Table 3). Livestock traffic has the potential to be infected by SE 4.8 times compared to buffalo cattle obtained from outside Aceh Barat District. The outbreak of SE disease in Aceh due to traffic flow [27]. The group of sensitive animals in endemic areas is only young animals whose maternal immunity has decreased or animals imported from non-endemic areas [17]. Based on the results of the study, it is feared that buffaloes originating from non-endemic areas (originating from outside Aceh Barat) will become sensitive animals and most likely will be very easily infected by SE disease if the animals make intense contact both directly and indirectly. Efforts to avoid the entry of disease into new areas through a strict livestock traffic control system with the main requirement is that animals must originate from areas without SE outbreaks for one year [6;24]. Endemic areas can become SE-free areas if vaccination has been carried out for three years in a row followed by epidemiological evaluation and laboratory testing [29].

The buffalo age factor has significant influence $(\mathrm{P}$ $<0.05)$ on the SE antibody titer where buffalo over 2 years have the opportunity to have an antibody titer 4.83 times compared to the age of cattle under 2 years. The SE endemic area is characterized by high morbidity and lower mortality of older animals compared to young animals because older animals already have antibody titers naturally so that their susceptibility is lower as well as these animals act as carrier animals [30] [31]. Sensitive groups of animals in endemic areas are young animals whose maternal immunity has decreased [17] [32]. Most cattle over the age of 18 months in endemic areas have natural antibody titers [7]. livestock of all ages are vulnerable to $\mathrm{SE}$, but the most vulnerable are cattle aged 6-24 months [33; 34]. The results of this study are very useful in the preparation of SE vaccination programs which are prioritized for buffaloes in sensitive age groups (<24 months).

\section{REFERENCES}

[1] https://databoks.katadata.co.id/datapublish/2016/09/07/acehprovince-with-most buffalo-population

[2] Department of Agriculture and Animal Husbandry of West Aceh District. Reports Strategic Disease West Aceh district. 2010. Meulaboh.

[3] Khan, A., U. Saddique, R. Ahmad, H. Khan, Mohammad Y., and M. Zubair. Sero surveillance of hemorrhagic septicemia in cattle and buffaloes in Malakand District, NWFP. Journal of Agriculture and Biological Science. 2006.

[4] Natalia L, and A. Priadi, Septicemia disease Epizootika: Research and Business control them on the cow and buffalo in Indonesia, National Workshop for Disease Control Availability of science and technology in Ruminant Strategic At Large. 2006.: 53-61.

[5] Saharee A.A and N. Salim. The epidemilogy of haemorrhagic septicemia in cattle and buffaloesin Malaysia. Proc. Of the Fourth International Workshop on Haemorrghagic Septicemia, Sri Lanka February 11-15, 1991, pp. 109-112.

[6] De Alwis, M.C.L. Haemorrhagic Septicemia, ACIAR monograph 57, 1990. p, 38

[7] Putra A.A.G Natural Immune Surveillance Against Substance Pasteurella multocida At Sentinel Cattle in the village on Lombok. Veterinary Bulletin. 2003. No.XV (62): 22-31.

[8] Sugiyono. Qualitative and Quantitative Research Methods R \& D. Publisher Alfabeta. 2008. Bandung.

[9] Australian Center for International Agricultural Research. (1993). Diagnosis and Control of Haemorrhagic Septicemia In Indonesia Commissioned Organization: Victorian Institute of Animal Science, Australia Collaborating Institutions: Research Institute for Veterinary Science, Indonesia Australia.

[10] Thursfield, M.. Veterinary Epidemiology. 2nd Edition. Blackwell Science. 1995. Oxford, England.

[11] De Alwis, MCL, Pasteurellosis in animal production; A review in pasteurollosis in production animals. 11-12, An International Workshop for Pasteurellosis, ACIAR. 1992. Bali, Indonesia.

[12] Hussain, R., A. Mahmood. FA Khan. Khan. MZ and Siddique. AB. Pathology and molecular-based study of pneumonic 
pasteurellosis in cattle and bufflo (Bubalus bubalis). Pakistan Journal of Agriculture. Science., 2014. Vol. 51 (1), 235-240; College of Veterinary and Animal Science, the Islamia University of Bahawalpur, Pakistan.

[13] Abubakar, MS and M. Zamri-saad and S.Jasni,. Ultrastructural changes and bacterial localization in buffalo calves following oral exposure to Pasteurella multocida B: 2. Pakistan Vet. J., 2012. 33 101-106.

[14] Munner, R., M. Zahoor Hussain and AB. Efficeacy of oil-based haemorrhagic septicemia vaccine: A Field Trial. Int. J. Agric., and Tech .2005. 7 (4): 571-573.

[15] Arjono S., H. Prabowo and Susilo FX Snoring disease outbreaks in South Lampung regency: Investigation of epidemiological and economic losses. Pros. National Seminar on Veterinary Epidemilogy to-1. Directorate of Animal Health, Directorate General of Livestock. 1989. p.35-50.

[16] Putra, A. A. G. Investigation of some aspects of the epidemiology of septicemia epizootica on a mini ranchdi Kupang. Bulletin Veterinary Animal Disease Investigation Center Region VI Denpasar, March 1992

[17] Carter, GR and MCL De Alwis. Haemorrhagic septicemia. In Adlam, C. and Rutter JM, Pasteurella and Pasteurellosis. Academic Press Limited, London. 1989. p. 131-160.

[18] Sudardjat S. Epidemiology of Animal Diseases. Directorate of Animal Health Directorate General of Livestock Department Pertanian. 1991. Jilid I.

[19] Gowrakkal M, M.Chandrashekar, S Bhajantri, J. Satav, GC Chandakala, A Mayanna, BC Byregowda, C Renukaprasad. Evaluation of immuno efficiency of hemorrhagic septicemia vaccine strains (vaccine seed). Asian Pac. J Trop Biomed. 2014. May; 4 (Suppl 1): S263-S267

[20] Tarmudji. Some Important Diseases At Buffalo in Indonesia. Veterinary Centers Bogor.Wartazoa 2003. Vol. 13. No.4.

[21] Putra, AAG. Disease surveillance SE on Sumbawa Island: 1 Eradication Program Evaluation, Veterinary Bulletin, BPPV Denpasar, 2005. 66 (18).

[22] Putra, AAG. Strategic situation of infectious animal diseases in large ruminants: surveillance and monitoring. National Workshop for Disease Control Availability of Science and Technology in Large Ruminant. Veterinary Investigation Centers VI. .2006. Denpasar.

[23] De Alwis, MCL, TG Wijewardana, AIU Gomis and AA Vipulasiri. Persistence of the carrier status in haemorrhagic septicemia
(Pasteurella multocida serotype 6: B infection) in buffaloes. Tropical Anim. Hlth. And Prod. 1999. (22): 185-194.

[24] Benkirane. A. and De Alwis MCL. Haemorrhagic septicemia, its significance, prevention and control in Asia, Vet Med, - Czech, 2002. 47 (8): 234-240.

[25] Ahmad, RZ. Diseases That Attack Buffalo in Indonesia, National Seminar and Workshop 2008 Buffalo Livestock Business.

[26] Sarah, Abusalab, Ahmed, AM and Hamid, ME Hemorrhagic septicemia, Journal Sudan. 2004. (23); 1-8.

[27] Suhirjan, Mahmud A. G. and Gunawan. Aspects of the epidemiology of snoring / SE in. Special Region Veterinary Bulletin. Animal Disease Investigation Center Region I. Directorate General of Livestock Project Pemebrantasan Animal Disease Prevention and North Sumatra Province. 1989. 41: 1-8.

[28] Natalia L and Priadi, A. Penyakit Septicemia Epizootica: Enterprises Disease Research and Control Them By Cow and Buffalo in Indonesia. 2000. Hal 53-63.

[29] Directorate General of Livestock and Animal Health Ministry of Agriculture. Guidelines for Control and Prevention Septicemia Epizootica. 2013. Jakarta.

[30] Wijewardana, Haemorrhagic septicaemia. Rev. Med. Microbiol. 1993. (3): 59-63

[31] Verma N. K., C. Mahajan, G. Malik, and J. P. Dahiya. An epidemiological study on bovine haemorrhagic septicemia in Haryana. Indian Janim.Res., 38 (1): 14 to 19. 2004 J College of Veterinary Sciences, CCS Haryana Agricultural University, Hisar-125 004, India.

[32] Shivachandra SB, Viswas KN, Kumar AA A review of hemorrhagic septicemia in cattle and buffalo. Animal Health Research reviews. 2011; 12 (1): 67-82. doi: 10.1017 / S146625231100003X. [PubMed] [Cross Ref],

[33] Khan, A., MK Saleemi, MZ Khan, ST Gul, M. Irfan and MS Qamar. Hemorrahgic Septicemia in Buffaloes (Bubalu bubalis) Sub-Tropic Calve Under Conditions in Pakistan. 2011. Department of Pathology, University of Agriculture, Faisalabad, Pakistan.

[34] Anjum, R., S Ahmed, M. Siddque, M. Abubakar. The prevalence of haemorrhagic septicemia of the cattle and Bufallo bubalis In Punjab Pakistan.IJAVMS, 2014. Vol.8, Issue 3, 2014: 57-63. 